\title{
Enforcement and Immigrant Location Choice
}

\section{Tara Watson}

\section{Abstract:}

This paper investigates the effect of local immigration enforcement regimes on the migration decisions of the foreign-born. Specifically, the analysis uses individual-level American Community Survey data to examine the effect of recent 287(g) agreements, which allow state and local law enforcement agencies to enforce Federal immigration law. The results suggest that one type of $287(\mathrm{~g})$ agreement - the controversial local "task force" model emphasizing street enforcement-nearly doubles the propensity for the foreign-born to relocate within the United States. The largest effects are observed among non-citizens with at least some college education, suggesting that $287(\mathrm{~g})$ policies may be missing their intended targets. No similar effect is found for the native-born. After the extreme case of Maricopa County is excluded, there is no evidence that local enforcement causes the foreign-born to exit the United States or deters their entry from abroad or from elsewhere in the United States. Rather, 287(g) task force agreements encourage the foreign-born to move to a new Census division or region within the United States.

\section{JEL codes: K00}

Tara Watson is a visiting scholar at the New England Public Policy Center in the research department of the Federal Reserve Bank of Boston, an associate professor of economics at Williams College, and a research associate at the NBER. Her email address is twatson@williams.edu.

The author would like to thank Kristin Butcher, Robert Clifford, Yolanda Kodrzycki, Darcy Saas, Alicia Sasser Modestino, Abigail Wozniak, Bo Yoon, and participants in the New England Public Policy Center brown bag seminar series for helpful comments.

The views expressed in this paper are those of the author only and do not necessarily represent the views of the Federal Reserve Bank of Boston or the Federal Reserve System.

This version: June 2013 


\section{Introduction}

The recent recession stemmed the tide of immigration into the United States, but the estimated foreign-born population exceeds 38 million individuals representing more than 12 percent of the population. Immigrants play an important role in local labor markets, both because they constitute a substantial portion of the workforce (15.8 percent in 2010) $)^{1}$ and because they are a key driver of workforce growth. Furthermore, location decisions of immigrants respond more to local labor market conditions than those of native-born workers and help to equilibrate differences across labor markets within the United States (Borjas 2001).

A sizable literature explores the location choices of immigrants within the United States. Much of this work focuses on immigrant ethnic networks (for example, Bauer, Epstein, and Gang 2005) and local economic conditions (for example, Borjas 2001, and Cadena and Kovak 2013). However, little is known about how the policy environment affects where immigrants choose to live within the United States.

The analysis presented here focuses on the under-represented role of local immigration policy, specifically the devolution of enforcement to local law enforcement that has occurred in the last decade through section 287(g) of the 1996 Immigration and Nationality Act. Since 2002, almost 80 state and local law enforcement agencies have signed 287(g) agreements. In some cases, these agreements are signed with the explicit intent of reducing the local immigrant population. Because enforcement decisions are made at a local level, they may influence immigrant decisions of where to settle in the United States.

As the nation debates immigration policy, understanding the impacts of enforcement on immigrants' behavior is critically important. The effect of immigration-related policies on residential choice is also of interest to local policymakers. If regions seek to boost labor force growth or change the local skill mix by changing the foreign-born population, it is important to understand what policies facilitate or discourage immigrant inflows. Conversely, as states and

\footnotetext{
${ }^{1}$ http://www.bls.gov/news.release/forbrn.nr0.htm
} 
local law enforcement agencies consider adopting immigration-related policies, it is important to know what implications these policies have for the composition of the local labor force. Enforcement activity in other parts of the country may also have direct implications for projected foreign-born inflows to areas with less aggressive enforcement activity. These impacts will be of particular interest to employers who rely on foreign-born labor.

This paper uses data from the American Community Survey to examine migration responses to local enforcement. The aggregate analysis presented first offers a bird's eye view of migration. One can estimate cross-national inflows to and outflows from an area as well as outflows from the United States by comparing numbers of immigrants in a local area in a given year, the number of immigrants remaining in the United States in the following year who indicate that they lived in the local area in the previous year, and the number of immigrants in the local area who said they lived abroad in the previous year. The results suggest that-once the extreme case of Maricopa County is excluded-international migration flows are not affected by local enforcement.

Data analyzed at the individual level offer more detail and elucidate four patterns that would not otherwise be evident. First, immigrants respond only to the task force model of 287(g) enforcement. Second, in most circumstances, immigrants responding to local enforcement relocate within the United States rather than leaving the country. The impact of full task force coverage on internal migration is similar to that of a 15 percent decline in predicted employment demand. Third, the degree of local enforcement affects the decision to leave an area but does not deter foreign-born inflows from arriving from elsewhere in the United States or abroad. Fourth, non-citizens who are more educated are more responsive to task force enforcement, suggesting that 287(g) policies may be missing their intended targets.

Finally, location choices are explored using a conditional logit approach. Rather than examining the determinants of migration directly, the conditional logit model estimates characteristics of places that immigrants find attractive, regardless of whether they already live in those locations. The results confirm that task force enforcement is viewed by non-citizens as an unappealing attribute of a local area. 


\section{Previous Literature}

There is a rich literature in economics and demography examining immigrant location choice within the United States. Analysts are particularly interested in location choice because it is central to understanding how immigration affects the labor market outcomes of the native-born within the U.S. For example, a number of papers have exploited the geographic distribution of immigrants over time to identify wage impacts. Because immigrants seek destinations with good labor market conditions, the analyses typically exploit exogenous variation in the geographic distribution. Many previous papers have used variations of the supply-push instrument pioneered by Card (2001), which uses the interaction of initial country-of-origin shares in a local area with national trends in immigrant inflows from those countries-of-origin. Borjas (2006) has argued that immigrant inflows lead to native outflows from a local area, so that the wage impacts of immigration are diffused across the country. While a full discussion of that debate is beyond the scope of this paper, understanding internal migration decisions of immigrants is a key input to understanding the national impacts of immigration.

Immigrant location decisions are also of interest in their own right. For example, immigrant location choices are believed to equilibrate wages across local labor markets within the United States (Borjas 2001; Cadena and Kovak 2013). Immigrant location decisions affect a wide range of other outcomes such as native residential location decisions (Wozniak and Murray 2012), local rents (Saiz 2003; Saiz 2007), native female labor supply (Cortes and Tessada 2011), firm production decisions (Lewis 2005), and school segregation (Cascio and Lewis 2012). A number of previous papers have examined the impacts of immigrant concentration in particular areas (Bertrand, Luttmer, and Mullainathan 2000; Funkhouser 2000; Jaeger 2007; and Edin, Fredriksson, and Aslund 2003). Researchers have also explored the impact of the safety net on immigrant location choice (Borjas and Hilton 1996; Borjas 1999; Dodson 2001; Buckley 1996).

The literature on the impacts of immigration enforcement is relatively new. At the national level, Ortega and Peri (2012) show that immigration restrictions do affect cross-country migration flows whereas Orrenius and Zavodny (2003) find no evidence that the 1986 amnesty for undocumented immigrants affected long-run migration flows. There are also several papers 
exploring the impacts of local enforcement on immigrant labor market outcomes. For example, see Davila and Pagan (1997), Bansak (2005), and Orrenius and Zavodny (2009). ${ }^{2}$ Watson (2010) documents impacts of enforcement on Medicaid participation among children of non-citizens.

Several recent papers have examined effects of local enforcement on migration using aggregate data. Bohn, Lofstrom, and Raphael (forthcoming) document declines in the foreign-born population in Arizona following restrictive state legislation. Kostandini, Mykerezi, and Escalante (2012) focus on the agricultural sector and find that local 287(g) enforcement reduced immigrant population, changed farm inputs, and reduced farm profits in affected counties. O’Neil (2013) finds no systematic relationship between 287(g) implementation and Hispanic or foreign-born population growth. The current analysis builds on existing studies by considering individual-level migration decisions, allowing for a more nuanced understanding of the relationship between enforcement and immigrant location choice.

\section{Recent Enforcement Policy}

Internal federal immigration enforcement has declined markedly over the past several years. This shift reflects both a decline in undocumented immigrants residing in the United States (there has been an estimated 8 percent decline in the unauthorized population since 2007) ${ }^{3}$ and a policy shift away from non-criminal apprehensions.

Despite declines in federal enforcement, there has been a recent increase in enforcement of immigration law by local entities. Section 287(g) of the 1996 Illegal Immigration Reform and Immigrant Responsibility Act offered the opportunity for local law enforcement officers to enforce federal immigration law after receiving training from U.S. Immigration and Customs Enforcement (ICE); prior to the Act, local law enforcement did not have jurisdiction over

\footnotetext{
${ }^{2}$ Davila and Pagan (1997) find evidence that monitoring of selected firms had impacts on employment, wages, and industry choice of immigrants. Bansak (2005) also finds that the 1986 Immigration Reform and Control Act adversely affected wages and employment for Mexican workers, and Orrenius and Zavodny (2009) find similar impacts as the result of recent enforcement policies.

${ }^{3}$ http://www.pewhispanic.org/2011/02/01/ii-current-estimates-and-trends/
} 
immigration-related matters. ${ }^{4}$ The 287 provision was largely ignored until the events of September 11, 2001 refocused national attention on immigration policy (Lacayo 2010), and starting in 2002 states and localities began to pursue 287(g) agreements. It took some time for the practice to become widespread, but as of 2011 (the end of the sample period for this analysis), there were 68 local law enforcement agencies in 23 states that were currently in one or more agreements with ICE to enable local enforcement. Most of 287(g) agreements were initiated in 2007 or later, as shown in Figure 1. A primary determinant of applying to the 287(g) program is local growth in the foreign-born population (Shahani and Greene 2009), whereas a large, long-standing, foreign-born population promotes integrative or inclusive policies (Boushey and Luedtke 2011).

The 287(g) program is controversial because it allows state and local law enforcement entities to apply to the federal government to play a role in enforcing immigration law, which has traditionally been the purview of federal officers. Agencies in the 287(g) program receive Federal training and are then allowed to perform enforcement functions. In areas with local task force $287(\mathrm{~g})$ agreements, officers are permitted to investigate immigration violations in the field and to ask individuals on the street for proof of legal presence if they have reasonable cause to suspect a violation. Other areas have "jail enforcement" agreements which facilitate the investigation of the legal status of those arrested for other crimes. Some agencies have combined task force and jail agreements (typically implemented at the same time). The resulting correlation between types of agreements is around 0.1 .

Detractors argue that $287(\mathrm{~g})$ encourages street harassment of minorities, while proponents view it as an effective tool in enforcing immigration law and encouraging "self-deportation." The Obama administration ended the task force portion of the 287(g) program at the end of 2012 in favor of other ICE programs enabling local enforcement such as the Secure Communities Program and the Criminal Alien Program.

\footnotetext{
${ }^{4}$ More generally, the 200-page 1996 Act expanded resources for enforcement, changed deportation procedures, revamped employer sanctions, and made a variety of changes to the legal immigration process.
} 
Despite the decline in the use of $287(\mathrm{~g})$, there has been a recent wave of state and local legislation targeting immigrants, most prominently illustrated by the far-reaching Arizona legislation (known as SB 1070) passed in April 2010. In 2012, the U.S. Supreme Court upheld one key portion of the law allowing police to check the immigration status of those they detain. "Copy-cat" state legislative activity has been reported in 26 states (http://www.nilc.org/stateimmenfleg-2012.html) and five states passed similar legislation in 2011. ${ }^{5}$ There are also numerous anti-immigrant bills at the local levels. Though the effects of the recent state legislation are not yet observable, the $287(\mathrm{~g})$ program offers some insight into the likely effects of these aggressive sub-national enforcement regimes.

More generally, states and localities make many policy decisions related to immigrants. States differ on the extent to which they offer safety net benefits to undocumented and legal immigrants. For example, about half of states exclude legal immigrants from welfare and Medicaid benefits for their first five years in the United States. Active policy discussions at the state level include whether undocumented students should pay in-state college tuition rates, whether undocumented immigrants should be allowed to obtain driver's licenses, and whether employers need to use electronic immigration status verification systems (E-Verify). On the other hand, many localities have issued policy statements indicating that they will not pursue enforcement actions under certain conditions; these jurisdictions have been informally dubbed "sanctuary cities." 6 There is little evidence on how immigrants weigh the complex local policy environment in their location decisions.

In sum, relatively little attention has been paid to the local enforcement regime and how it affects where the foreign-born live. As noted above, recent papers on the subject (Kostandini, Mykerezi, and Escalante (2012); O’Neil 2013) have mixed findings. This paper uses individual-

\footnotetext{
${ }^{5}$ Alabama, Georgia, Indiana, South Carolina, and Utah passed similar laws in 2011. According to the national conference of state legislatures, "[t]he laws typically include provisions that require law enforcement to attempt to determine the immigration status of a person involved in a lawful stop; allow state residents to sue state and local agencies for noncompliance with immigration enforcement; require E-Verify; and make it a state violation for failure to carry an alien registration document" (http://www.ncsl.org/issues-research/immig/omnibus-immigrationlegislation.aspx). The laws have been wholly or partly enjoined pending legal challenges.

${ }^{6}$ The designation "sanctuary city" is unofficial and there is disagreement over what types of policy regimes should qualify.
} 
level data to analyze how the $287(\mathrm{~g})$ program affects year-to-year migration flows within the United States.

\section{Data and Methods}

The primary data source used in the analysis is the American Community Survey (ACS) for years 2005-2011 provided by the Integrated Public Use Microdata Series (Ruggles et al. 2010). The ACS is a large, nationally representative survey run by the Census Bureau. Importantly, the ACS collects information on birthplace, citizenship, and residence in the year prior to the survey. Thus, it is possible to construct one-year migration estimates for six cohorts (2005-2010) and to observe detailed migration decisions for immigrants living in the United States for two consecutive years. ${ }^{7}$ Because the ACS is relatively new, it has not been used very often to examine sub-state migration patterns. ${ }^{8}$

The publicly available Census/ACS provides 543 geographic units that are consistently identified over time and cover the entire United States. In cases where there are multiple such units within a metropolitan area (defined according to 2000 boundaries) I combine areas; this sometimes requires combining metropolitan areas or a metropolitan area and a rural area into a single geographic region. The end result is 338 local geographic areas used for analysis. The local areas are defined so that they do not cross state lines. These areas are shown in Figure 2, with task force agreement areas outlined in red.

The 287(g) agreement data are collected by examining current and historical agreements posted on the ICE website, ${ }^{9}$ screenshots of the website from earlier periods, published reports including Lacayo (2010) and Vaughan and Edwards (2009), and news reports. These sources were used to construct start and end dates for all 287(g) agreements that existed at any time; in

\footnotetext{
7 "Immigrant" as defined here includes everyone born outside the 50 United States and Washington, D.C. who was not a citizen at birth. "Native" includes everyone born within the 50 United States and Washington, D.C. Individuals with citizenship at birth born in outlying areas (including Puerto Rico) are not considered immigrants or natives, but are included in the analysis. The results are not sensitive to their classification.

8 Wozniak and Murray (2012) were among the first to use it for this purpose.

${ }^{9} \mathrm{http}: / / \mathrm{www} . \mathrm{ice} . \mathrm{gov} / 287(\mathrm{~g}) /$ contains a list of current agreements and some historical documents.
} 
six cases end dates were not known to the exact month and were approximated based on available information.

Enforcement agreements can cover local police jurisdictions or states. Given that Kostandini, Mykerezi, and Escalante (2012) have found differential effects of local versus state agreements, I separate them in the analysis. For local agreements, the enforcement index indicates the fraction of the population in the local area (which may include several jurisdictions) living in a jurisdiction covered by an agreement. ${ }^{10}$ For populations covered by more than one agreement (for example, a county police force and a city police force both have agreements that cover a city) the enforcement coverage is counted twice. If the agreement was not in effect for the full year, the value of the index is the average over the year. Local task force agreements and local jail enforcement agreements are analyzed separately because they have different features and may generate differing migration responses. The statewide agreement variable takes a value of zero or one except when the agreement is in effect for only part of the year. Results are similar if each type of $287(\mathrm{~g})$ agreement (local task force, local jail enforcement, statewide) is included alone in a regression model, but the regressions shown below include the three enforcement variables.

The analysis is composed of three parts. First, I aggregate ACS data by year and initial local area, and estimate migration decisions for the population initially residing in the area. By comparing the population in the ACS who report the local area as their place of residence in the prior year to the population residing there in the prior ACS year, it is possible to construct exit rates from the United States and migration to an area from abroad. ${ }^{11}$ Because the ACS is a sample, it is possible to estimate negative migration rates - that is, in some cases there are more people in year $t$ reporting that they lived in a given area in $t-1$ than there are people counted in

\footnotetext{
${ }^{10}$ Local areas are combinations of Census public use microdata areas and may include several cities or counties. Local law enforcement agencies typically operate at the county, city, or town level and are fully enclosed within one local area. For example, if 25 percent of the overall population in a local area reside in County $\mathrm{X}$, and County $\mathrm{X}$ is the only part of the local area that has an agreement, then local area coverage is 0.25 .

${ }^{11}$ For example, one might estimate that there are 10,000 immigrants in Local Area X in 2005 using 2005 ACS data. Using 2006 ACS data, one can then estimate the number of people living in the United States in 2006 who report living in Local Area $X$ last year. If that number is 9,900, the estimated out-migration rate from the United States would be 1 percent.
} 
the area in $t-1$. These are entered into the analysis without adjustment. ${ }^{12}$ Death is indistinguishable from exiting the United States in the data; I restrict the sample to those ages 1 to 65 to minimize the impact of death on the estimates.

The aggregate part of the analysis also uses aggregated individual-level year-to-year migration flows to construct internal migration statistics. For example, one can observe the fraction of individuals living in area $a$ in time $t$ who subsequently move to a different local area, state, Census division, or Census region by time $t+1$ as a function of local characteristics in time $t$. The denominator here can be the local area population estimated using the year $t$ ACS data or the local area population estimated using migration history in the year $t+1$ ACS data. The latter increases precision and is used to estimate internal migration conditional on remaining in the United States.

The empirical model is as follows:

$$
\begin{gathered}
\text { FractionMoved }_{a t}=\text { B1TaskForceIndex }_{a t}+\text { B2JailEnforcementIndex }_{a t}+ \\
\text { B3StatewideIndex } \\
\text { Bt }
\end{gathered}
$$

The key coefficients indicate the effect of enforcement on the fraction of the population in local area $a$ in year $t$ that moved by the following year. A vector of controls includes a Bartik-style shift-share index for local labor demand generally and a second Bartik index for immigrantspecific labor demand. ${ }^{13}$ These are important controls because the sample time frame coincides with the Great Recession. Predicted immigrant population is a supply-push-style index based on national country-of-origin trends interacted with initial country-of-origin shares. I also control for the fraction of the population arriving in the last five years because this may affect migration patterns.

\footnotetext{
${ }^{12}$ Lleras-Muney (2005) faces a similar issue in the context of synthetic cohort mortality rates. She notes that using the estimated rates does not affect the consistency of the estimates.

${ }^{13}$ Specifically, for each local area the initial (year 2005) employment share in each of 15 industry groups is determined. These shares are then interacted with the difference between log employment in the industry in the reference year and log employment in the industry in the initial year. These interactions of these shares*shifts are aggregated to generate an index of predicted labor demand in each local area relative to 2005 . In the immigrantspecific index, the initial share weights are determined by the industry distribution of the initial immigrant population.
} 
The regressions include year dummies to account for national migration trends and local area dummies to account for permanent characteristics of locations that may affect migration. As an additional outcome, I also examine new migrant inflows divided by the initial foreign-born population. The regressions are weighted by 2005 immigrant population and the standard errors are clustered at the local area level to account for serially correlated local shocks.

Panel A of Table 1 reports summary statistics for the 2028 local area-years in the aggregate analysis. The average out-migration from the United States is about 1 percent and the internal regional migration rate is about 1 percent conditional on staying in the United States. The average task force coverage is 2 percent, suggesting a low rate of exposure to the policy.

The second part of the analysis exploits the individual-level micro-data, allowing one to observe migration decisions for individuals who were living within the United States for two consecutive years. This part of the analysis examines determinants of migration for foreign-born residents staying in the United States for two consecutive years. The sample is restricted to noninstitutionalized adults ages 18 to 49 to focus on the individual-level migration decision among those most likely to be making such a decision. Children and older adults are excluded from this part of the analysis. The empirical model is similar to the one above except that the analysis is at the individual level and allows for individual-level controls:

$$
\begin{gathered}
\text { Moved }_{\text {iat }}=\text { B1TaskForceIndex }_{a t}+\text { B2JailEnforcementIndex }_{a t}+ \\
\text { B3StatewideIndex } \\
\text { Bt }
\end{gathered}
$$

The summary statistics for the individual-level data are shown in Table 1B. The individual level analysis controls for whether the immigrant arrived in the last five years, gender, marital status, educational attainment in four categories (less than high school, high school, some college, college grad or more), age in two categories (18-29 or 30-49) and country of birth in 22 categories.

Third, a conditional logit analysis of individual decisionmaking is employed. The conditional logit is a discrete choice model that allows one to identify how characteristics of potential residential locations affect the choice among alternatives (McFadden 1974). In the conditional 
logit model, each individual chooses exactly one utility-maximizing alternative from the set of 338 unordered potential residential choices. The utility value of each choice is determined by its attributes (potentially interacted with information about the individual) and an error term. The variable $y_{i j}=1$ if an individual $i$ chooses local area $j$ and $y_{i j}=0$ otherwise. Under assumptions outlined in McFadden (1974), one can use the conditional logit model to estimate the probability that any given choice provides greater utility than all other choices. ${ }^{14}$ Only characteristics that vary across destinations can be included in the estimation model.

The conditional logit analysis examines how enforcement affects the probability of choosing a particular destination. Additional controls include local labor market conditions (the Bartik immigrant index), the predicted immigration index, the share of same-group immigrants in the area, and a dummy for whether the destination is the same as the origin interacted with year of arrival, male, and education. ${ }^{15}$ The analysis also controls for average pairwise flows between an origin and destination to account for all fixed characteristics that might affect movement between two places, such as distance, economic and cultural similarity, and relative size.

Due to the computational demands of the conditional logit, results are estimated for a subsample of migrants: 18-to-29-year-old non-citizens with at least some college. This group is chosen because the migration analysis indicates that more educated and younger non-citizens are most responsive to enforcement policy. Standard errors are clustered at the level of the initial location.

\section{Results}

\section{A. Aggregate Analysis}

\footnotetext{
14 The conditional logit assumes independence of irrelevant alternatives. This assumption is a poor one in cases where some of the choices are close substitutes. Christiadi and Cushing (2007) show that for estimation of migration decisions within the United States, the conditional logit yields coefficients of similar magnitude and significance to more computationally difficult models that partially or fully relax the assumptions.

${ }^{15}$ Because of collinearity between the overall Bartik index and the immigrant-specific Bartik index, results are unstable when both variables are included. Therefore, analyses with the immigrant-specific Bartik index are presented.
} 
Table 2 shows the results of the aggregate analysis of cross-border migration. The unit of observation is the local area-year, where local areas are defined as described above. The advantages of the aggregate analyses are that (1) they most closely follow previous work and (2) they allow for estimation of exits from the United States in a way that is not possible in the individual-level migration data. Because the results are sensitive to the inclusion of Maricopa County, Arizona-a local area with extreme levels of enforcement-estimates are shown with and without this area included.

Of the three types of 287(g) agreements (local task force, local jail enforcement, and statewide), only task force agreements have statistically significant impacts on cross-border migration. Column I suggests that full coverage of a local area with a task force agreement increases the fraction of the initial population that exits the United States in the subsequent year by 10.4 percentage points, a dramatic increase over the mean of 1.3 percent. However, the relationship between enforcement and exits is driven entirely by the inclusion of Maricopa County. Maricopa County (which includes Phoenix and surrounding areas) is known for intensive and often controversial enforcement tactics under the leadership of Sheriff Joe Arpaio. Thus, the intensity of enforcement in this area is unusual. Furthermore, because the area is also only a few hours from the Mexican border, out-migration may be a more attractive response in Maricopa than it would be elsewhere. Excluding Maricopa, there is no evidence that 287(g) enforcement drives out-migration from the United States, as shown in column II.

Table 2 also shows the impact of 287(g) enforcement on inflows from abroad to a particular local area. In the full sample, it does appear that enforcement reduces inflows from abroad. Full local task force coverage yields a reduction of inflows by 1.2 percentage points on a base of 3.2 percent. Again, these results are sensitive to the inclusion of Maricopa County. Outside of Maricopa, there is no measurable impact of enforcement on inflows from abroad to a local area. Jail enforcement agreements and statewide enforcement have no measurable impact on outmigration or inflows.

Table 3 investigates the effect of enforcement on internal migration (conditional on staying in the United States) and inflows from other parts of the United States. Panels A and B show 
results for immigrants with and without Maricopa County included. In both cases, local task force agreements increase the probability of relocation within the United States. For example, the fraction of immigrants moving out of state increases 0.99 to 1.38 percentage points (45 to 63 percent increase over baseline), out of the Census division increases 0.83 to 1.58 percentage points (52 to 99 percent increase over baseline), and out of the Census region increases 0.54 to 0.96 percentage points ( 45 to 80 percent over baseline).

Interestingly, task force agreements do not appear to affect inflows from other parts of the United States, as shown in the final column of Table 3. This result suggests that task force agreements act as a "push" to prompt relocations from an area but do not affect "pull" by deterring new arrivals. There is little evidence that the jail enforcement or statewide agreements affect migration decisions.

An obvious concern is that unobserved economic factors that coincide with task force policies are driving immigrants away from task force areas. One way to examine this possibility is to investigate the effect of enforcement on the native-born as a placebo test. Panels C and D reject the notion that $287(\mathrm{~g})$ agreements drive native out-migration. Therefore it seems likely that the migration of immigrants is due to immigrant-specific policy changes rather than unobserved economic conditions. ${ }^{16}$

In sum, the aggregate analysis suggests that task force $287(\mathrm{~g})$ agreements encourage immigrants to leave a local area and relocate to other parts of the United States. Outside of the extreme example of Maricopa County, there is no evidence that 287(g) agreements affect international flows.

\section{B. Individual Analysis}

Analysis of the individual migration decision for foreign-born individuals who remain in the United States for two consecutive years is shown in Table 4. The analysis is restricted to the

\footnotetext{
${ }^{16}$ It is important to keep in mind that the foreign-born may respond differently than natives to economic conditions, as suggested by Cadena and Kovak (2013). In Table A1, unemployment rates rather than Bartik instruments are used as an alternative control for local economic conditions. The results are not sensitive to this change.
} 
non-institutionalized population ages 18 to 49 , and results are shown with and without Maricopa County. ${ }^{17}$

The results suggest that implementation of task force agreements increase the probability of a foreign-born adult moving out of the local area, state, division, and region. For example, estimates from the full sample imply that full task force coverage increases the probability that an immigrant will choose to exit the state by 1.10 percentage points, the Census division by 0.98 percentage points, and the Census region by 0.77 percentage points. Results excluding Maricopa County are larger in magnitude-1.41 percentage points, 1.82 percentage points, and 1.22 percentage points, respectively. These figures are similar to what was estimated in the aggregate analysis and represent 40 percent to nearly 100 percent increases over baseline migration levels. The fact that the effect on state and divisional migration is of comparable magnitude to local area migration implies that those who are induced to leave their local area typically leave the division entirely. As in the aggregate analysis, there is no evidence that jail enforcement or statewide agreements cause migration out of a local area.

The coefficients on the controls offer further insight into migration behavior of immigrants. Immigrants are more likely to leave an area if employment demand for their skills is weak, if there is a decline in the predicted immigrant population in their area, if they arrived to the United States within the last five years, if they are male, if they are unmarried, if they are more educated, or if they are young adults ages 18-29 (results not shown). For purposes of comparison, column VIII suggests that a 15 percent decrease in immigrant-specific labor demand has a similar impact on regional migration as full local task force coverage. Migration rates are not statistically different across years after controlling for other factors (results not shown), but year dummies are included in all models.

As in the aggregate analysis, it is important to consider the possibility that unobserved economic factors are driving migration away from an area. The regressions include two Bartik-

\footnotetext{
${ }^{17}$ Enforcement has a positive but statistically insignificant effect on institutionalization. Results are similar if the institutionalized population is included in the sample.
} 
style controls for employment demand but may not fully capture local economic shocks. ${ }^{18} \mathrm{I}$ consider two versions of a placebo test using the native-born. One simply repeats the analysis with a native-born sample. The second reweights the native sample so that its characteristics more closely approximate the immigrant sample, where cells are determined by initial local area, sex, age category (18-29 or 30-49), and education category (no high school degree, high school degree exactly, some college, college graduate or more). The results of the exercise are shown in Table 5. Panel A shows estimates for immigrants, Panel B shows estimates for natives, and Panel $\mathrm{C}$ shows the estimates for re-weighted natives as described above. Maricopa County is excluded, but the results are not qualitatively sensitive to that decision.

Regardless of re-weighting, results for natives are generally negative and insignificant. The difference between immigrants and natives in a fully interacted model is shown in Panel D. There are significant differences between immigrants and natives; immigrants are 1.7-2.3 percentage points more likely than natives to move out of an area under a task force enforcement regime.

The robustness of the relationship between enforcement and immigrant migration is examined in Appendix Table 1. ${ }^{19}$ Baseline results for cross-divisional moves and cross-regional moves are shown in column I and column VII. Columns II and VIII show results without demographic controls; results are largely unchanged. Columns III and IX evaluate the impact of using unemployment rates rather than Bartik instruments to model the economic climate. Unemployment rates are advantageous in that they capture idiosyncratic shocks in a way that the Bartik measures do not. However, they also respond directly to the migration rate and therefore are not a preferred measure of economic conditions. Nevertheless, results are similar to the baseline when the unemployment rate is used as an alternative to the Bartik measure.

Columns IV and $\mathrm{X}$ address the possibility that alternative immigrant-specific policies affect migration and confound the estimated effects of $287(\mathrm{~g})$. For example, a control is included for

\footnotetext{
${ }_{18}$ Controlling for the unemployment rate is inappropriate because it is directly affected by out-migration. Nevertheless, results are similar if unemployment rather than Bartik demand measures are used, as shown in Appendix Table 1.

${ }^{19}$ All models in Appendix Table 1 omit Maricopa County.
} 
whether the state allows the undocumented residents to receive in-state tuition benefits. Although this policy arena has been active very recently, there were only three state changes between 2005 and 2010. The model also includes a dummy indicating whether any electronic employment verification (E-Verify) was mandated at the time in the state. During the study period, most of the e-verify laws in effect only applied to a small portion of employers in the state. The analysis lacks the statistical power to evaluate the effects of these state policies, but the controls do not affect the main results.

There may be additional unobserved state-level policies that affect the foreign-born. For example, Bohn, Loftstrom, and Raphael (forthcoming) find a migration response associated with a 2007 Arizona law. To address the possibility that idiosyncratic state laws are driving the results, columns $\mathrm{V}$ and $\mathrm{XI}$ repeat the exercise using state*year fixed effects. These models rely solely on within-state variation over time to identify the effects of $287(\mathrm{~g})$. Controlling for state $^{*}$ year effects does not substantively affect the results.

Finally, using a logit rather than a linear probability model yields positive and statistically significant effects for task force enforcement. Columns VI and XII report odds ratios from the logit models. The coefficients imply that the odds of migrating are more than doubled under full task force coverage. As in the linear probability model, there is no significant impact for jail enforcement or statewide enforcement.

Table 6 shows the divisional and regional migration response by citizenship status and education level. "More educated" immigrants are defined as those with some college or more. The largest and most statistically significant response is for more educated non-citizens. This group increases divisional migration by 4.2 percentage points and increases regional migration by 2.9 percentage points in response to task force enforcement. The larger response is not surprising given the fact that this group has the highest baseline levels of mobility, but the coefficients are large in absolute terms; they represent a more than doubling of migration rates. Further analysis (not shown) indicates that within the more educated group it is college graduates who are most responsive. The concentration of migration effects for more educated 
non-citizens and relative absence for less educated non-citizens suggests that localities using task force enforcement may be missing their intended targets.

\section{Conditional Logit Analysis}

The conditional logit model allows one to examine attributes considered by the foreign born as they select a location within the United States. As described above, the conditional logit is estimated for a sample of 18-to-29-year-old non-citizens who have at least some college and have lived in the United States for two consecutive years.

Results are presented in Table 7. Column I considers a simple model for the full sample, which includes the three enforcement variables and the average pairwise flow from the initial origin to the potential destination. The origin-destination control linearly accounts for all permanent characteristics of an origin-destination pair that might influence the typical flows between areas. Thus, the estimation strategy exploits the fact that task force enforcement varies over time within potential destinations.

The results in column I confirm that individuals are less likely to choose a location when there is task force enforcement. The presented odds ratios suggest that the odds of choosing a location are roughly cut in half when there is full task force coverage. Results are similar when Maricopa County is excluded, as shown in column II.

Columns III and IV add extra control variables-immigrant-specific employment demand, the fraction of same-origin immigrants in the area, the predicted number of immigrants overall, and demographic variables interacted with whether the potential destination is the same as the initial destination. The coefficient on task force enforcement is largely unchanged, although it is rendered statistically insignificant in column III. The odds ratio in Column IV suggests that the odds of selecting an area with task force enforcement is 40 percent of the odds of selecting an area without, after accounting for typical flows to the area.

The conditional logit model confirms the results on task force enforcement from the previous section. Interestingly, the results suggest a different pattern of results for jail enforcement. In the 
conditional logit model, such agreements appear to increase the odds that an immigrant will choose a given area. This result highlights the potential of differential response to different forms of enforcement.

These results are not supported by the main analysis, so they should be interpreted with caution. Nevertheless, detailed migration analysis suggests that foreign-born college graduates are less likely to exit an area in the presence of a jail enforcement agreement (analysis not shown). It is possible that college graduates are eager to leave areas in which hostility to the foreign-born is evident at the street level, but that they benefit from the removal of criminals who have been arrested. Further investigation is necessary before this conjecture can be verified.

\section{Magnitude of the Impacts}

Task force agreements have not been implemented widely across the United States, so their current impacts are not expected to be very large. At the peak of the agreements, only 3.5 percent of the immigrant population was exposed. The implied partial equilibrium impact of these agreements can be determined using the estimated regional migration coefficient, the baseline immigrant population, and the task force coverage across local areas. This exercise suggests that there were an extra 10,000 relocations of 18-to-49-year-olds to other Census regions in the peak year 2009 due to task force agreements. The cumulative effect over the sixyear sample period is 35,000. This number is small enough to conclude that there were not major distributional shifts of the foreign-born workforce across the United States as the result of 287(g) enforcement.

Task force agreements were curtailed at the end of 2012, but since 2010 states have used 287(g) as a model for legislative initiatives designed to bolster enforcement below the federal level. The impacts of these laws are yet to be seen, but the most extreme case would be one in which the effects of Arizona SB 1070 and similar bills in five other states resembled the impact of a local task force initiative. I perform a simulation which imagines that six states implement laws having the same impact as full task force coverage. Full coverage of six states - Alaska, Arizona, 
Georgia, Indiana, South Carolina, and Utah-would affect about 10 percent of all immigrants. Partial equilibrium simulations suggest that about 43,000 of them would be induced to relocate to a different Census division annually as a result of the laws. These flows are not large relative to baseline annual flows of about 450,000 , but they could be noticeable in certain areas.

\section{Conclusion}

This analysis investigates the impact of local immigration enforcement on migration choice. The results suggest that $287(\mathrm{~g})$ task force agreements do not cause out-migration from the United States except in extreme cases. Instead, task force agreements cause relocations across local areas, states, divisions, and regions within the United States. Importantly for policymakers, the effects are concentrated among more educated non-citizens. These individuals are more likely to be documented (although their legal status is not observable in the data) and are likely to be productive workers in the economy. Thus, the task-force enforcement regimes may be missing their intended targets.

The overall magnitude of migration induced by the task force policies is modest due to the relatively small scale of the $287(\mathrm{~g})$ program and the fact that only a small fraction of the foreignborn relocate each year. As a result, any one region is unlikely to receive a large number of immigrants as the consequence of strict enforcement elsewhere. Regional policymakers need not fear that a weak enforcement regime will lead to major demographic changes in their area.

As the country considers immigration reform, it is important to consider the effects of enforcement action more generally. Even though the task force model itself has been eliminated, widespread implementation of enforcement regimes like the task force model could drive a redistribution of immigrants within the United States. It is enforcement involving street harassment that appears to affect internal migration decisions. Current federal immigration policy is moving to expand the Criminal Aliens and Secure Communities Programs. Although both programs focus on individuals charged with a crime, both are criticized for incentivizing street harassment by law enforcement authorities. Policymakers seeking to retain skilled immigrants should consider their enforcement regimes accordingly. 
More broadly, the results suggest that, in addition to economic opportunity and social networks, the local policy environment influences location choice among the foreign-born within the United States. Full task force coverage has about the same impact on internal migration as a 15 percent decline in employment demand for immigrants. The distribution of the foreign-born in the United States is likely to evolve gradually as the result of local enforcement policy. 


\section{References}

Bansak, Cynthia, 2005. "The Differential Wage Impact of the Immigration Reform and Control Act on Latino Ethnic Subgroups," Social Science Quarterly, 86(1), 1279-1298.

Bauer, Thomas, Gil S. Epstein, and Ira N. Gang, 2005. “Enclaves, language, and the location choice of migrants," Journal of Population Economics, 18(4), 649-662.

Bertrand, Marianne, Erzo F. P. Luttmer and Sendhil Mullainathan, 2000. "Network Effects And Welfare Cultures," Quarterly Journal of Economics, 115(3), 1019-1055.

Bohn, Sarah, Magnus Loftsrom, and Stephen Raphael, forthcoming. "Did the 2007 Legal Arizona Workers Act Reduce the States Unauthorized Immigrant Population?" Review of Economics and Statistics.

Borjas George J., 1999. "Immigration and Welfare Magnets." Journal of Labor Economics, 17(4), 607-637.

Borjas, George J., 2001. "Does Immigration Grease the Wheels of the Labor Market?," Brookings Papers on Economic Activity, 2001(1), 69-119.

Borjas, George J., 2006. "Native Internal Migration and the Labor Market Impact of Immigration," Journal of Human Resources, 41(2), 221-258.

Borjas, George J., and Lynette Hilton, 1996. "Immigration and the Welfare State: Immigrant Participation in Means-Tested Entitlement Programs," The Quarterly Journal of Economics, 111(2), 575-604.

Boushey, Graeme, and Adam Luedtke, 2011. "Immigrants across the U.S. Federal Laboratory : Explaining State-Level Innovation in Immigration Policy," State Politics and Policy Quarterly, 11(4), 390-414.

Buckley, F.H., 1996. “The Political Economy of Immigration Policies," International Review of Law and Economics, 16, 81-99.

Cadena, Brian C., and Brian Kovak, 2013. “Immigration, Internal Migration, and Local Labor Market Adjustment During the Great Recession," unpublished manuscript.

Card, David, 2001. "Immigrant Inflows, Native Outflows, and the Local Labor Market Impacts of Higher Immigration," Journal of Labor Economics, 19, 22-64. 
Cascio, Elizabeth U., and Ethan G. Lewis, 2012. "Cracks in the Melting Pot: Immigration, School Choice, and Segregation," American Economic Journal: Economic Policy, 4(3), 91-117.

Cortes, Patricia, ad Jose Tessada, 2011. "Low-Skilled Immigration and the Labor Supply of Highly Skilled Women," American Economic Journal: Applied Economics 3, 88-123.

Christiadi and Brian Cushing. 2007. Conditional Logit, IIA, and Alternatives for Estimating Models of Interstate Migration. Regional Research Paper 2007-4.

Davila, Alberto, and Jose A. Pagan. 1997. “The Effect of Selective INS Monitoring Strategies on the Industrial Employment Choice and Earnings of Recent Migrants," Economic Inquiry, 35(1), 138-150.

Dodson, Marvin E., 2001. "Welfare Generosity and Location Choices among new United States Immigrants," International Review of Law and Economics, 21, 47-67.

Edin, Per-Anders, Peter Fredriksson, and Olof Aslund, 2003. "Ethnic Enclaves and the Economic Success of Immigrants-Evidence from a Natural Experiment," Quarterly Journal of Economics, 118(1), 329-357.

Funkhouser, Edward, 2000. "Changes in the Geographic Concentration and Location of Residence of Immigrants," International Migration Review, 34(2), 489-510.

Jaeger, David A. 2007. "Green Cards and the Location Choices of Immigrants in the United States, 1971-2000," in Barry R. Chiswick (ed.) Immigration (Research in Labor Economics, Vol. 27). Emerald Group Publishing Limited, 131-183.

Kostandini, Genti, Elton Mykerezi, and Cezar Escalante, 2012. “The Impact of Immigration Enforcement on the Farming Sector," unpublished manuscript.

Lacayo, A. Elena, 2010. “The Impact of Section 287(g) of the Immigration and Nationality Act on the Latino Community," National Council of La Raza Issue Brief 21.

Lewis, Ethan, 2005. "Immigration, Skill Mix, and the Choice of Technique," Federal Reserve Bank of Philadelphia Working Paper 05-8, 2005.

Lleras-Muney, A. , 2005. "The Relationship between Education and Adult Mortality in the United States," The Review of Economic Studies, 72(1), 189-221. 
McFadden, Daniel, 1974. "Conditional Logit Analysis of Qualitative Choice Behavior," Frontiers in Econometrics 105, 105-142.

O'Neil, Kevin, 2013. "Immigration Enforcement by Local Police under 287(g) and Growth of Unauthorized Immigrant and Other Populations," University of Cape Town Working Paper.

Orreinus, Pia M. and Madeline Zavodny, 2003. “Do Amnesty Programs Reduce Undocumented Immigration? Evidence from IRCA," Demography, 40(3), 437-450.

Orrenius, Pia M., and Madeline Zavodny, 2009. “The Effects of Tougher Enforcement on the Job Prospects of Recent Latin American Immigrants," Journal of Policy Analysis and Management, 28(2), 239-257.

Ortega, Francesc, and Giovanni Peri, 2013. "The Effect of Income and Immigration Policies on International Migration," Migration Studies, 1(1), 47-74.

Ruggles, Steven, J. Trent Alexander, Katie Genadek, Ronald Goeken, Matthew B. Schroeder, and Matthew Sobek, 2010. Integrated Public Use Microdata Series: Version 5.0 [Machinereadable database]. Minneapolis: University of Minnesota.

Saiz, Albert, 2003. "Room in the Kitchen for the Melting Pot: Immigration and Rental Prices," Review of Economics and Statistics, 85(3), 502-521.

Saiz, Albert, 2007. "Immigration and Housing Rents in American Cities," Journal of Urban Economics, 61(2), 345-371.

Shahani, Aarti, and Judith Greene, 2009. Local Democracy on ICE: Why State and Local Governments Have No Business in Federal Immigration Law Enforcement (Brooklyn, NY: Justice Strategies, 2009), http://www.justicestrategies.org/sites/default/files/JSDemocracy-On-Ice.pdf

Vaughan, Jessica M., and James R. Edwards, Jr., 2009. “The 287(g) Program: Protecting Home Towns and Homeland," Center for Immigration Studies Backgrounder.

Watson, Tara, 2010. "Inside the Refrigerator: Immigration Enforcement and Chilling in Immigrant Medicaid Participation." National Bureau of Economic Research Working Paper 16278.

Wozniak, Abigail, and Thomas J. Murray, 2012. “Timing is Everything: Short Run Population Impacts of Immigration in U.S. Cities," Journal of Urban Economics, 72(1), 60-78. 


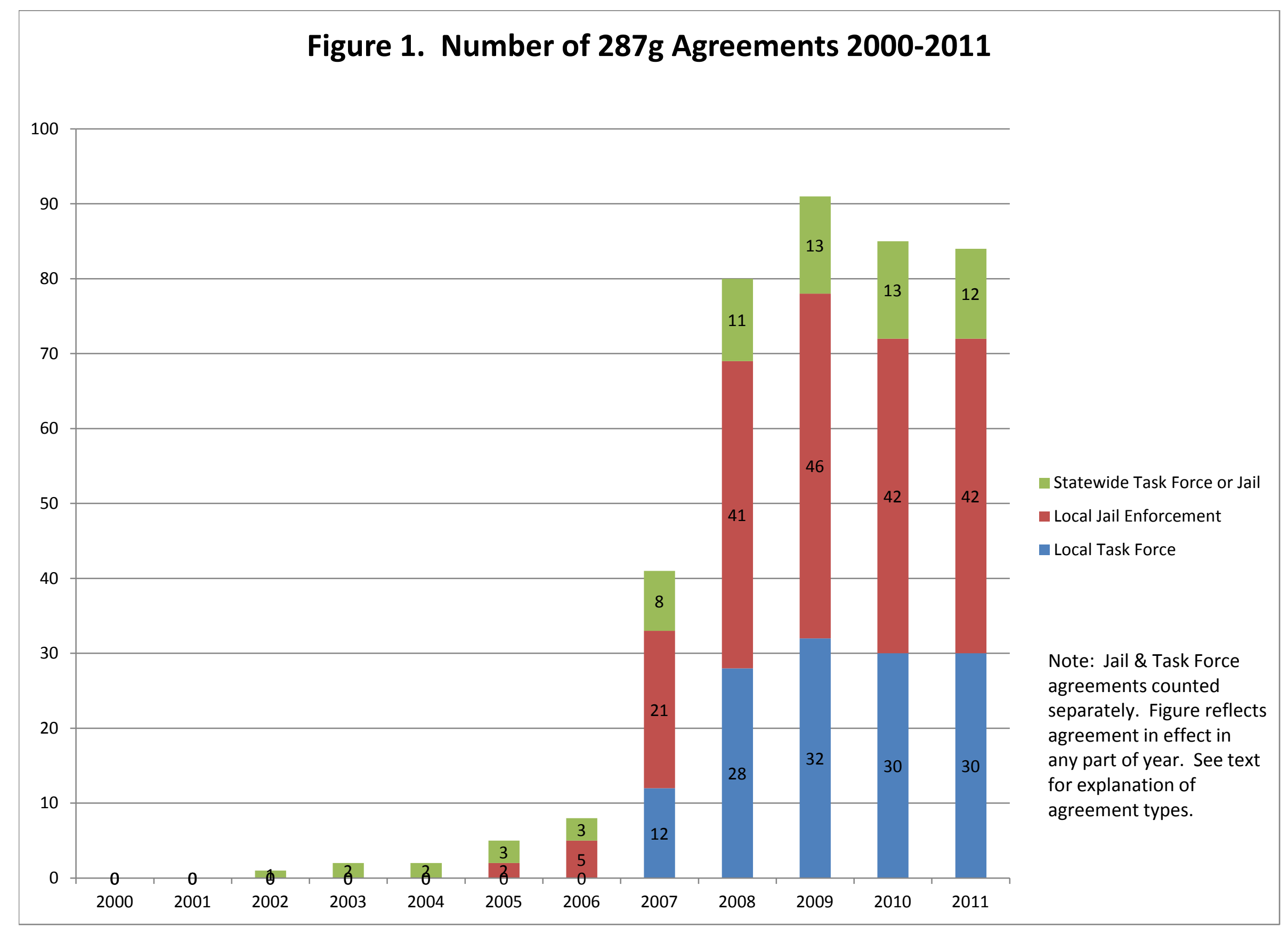


Figure 2. Map of Local Areas With Task Force Locations Outlined in Red

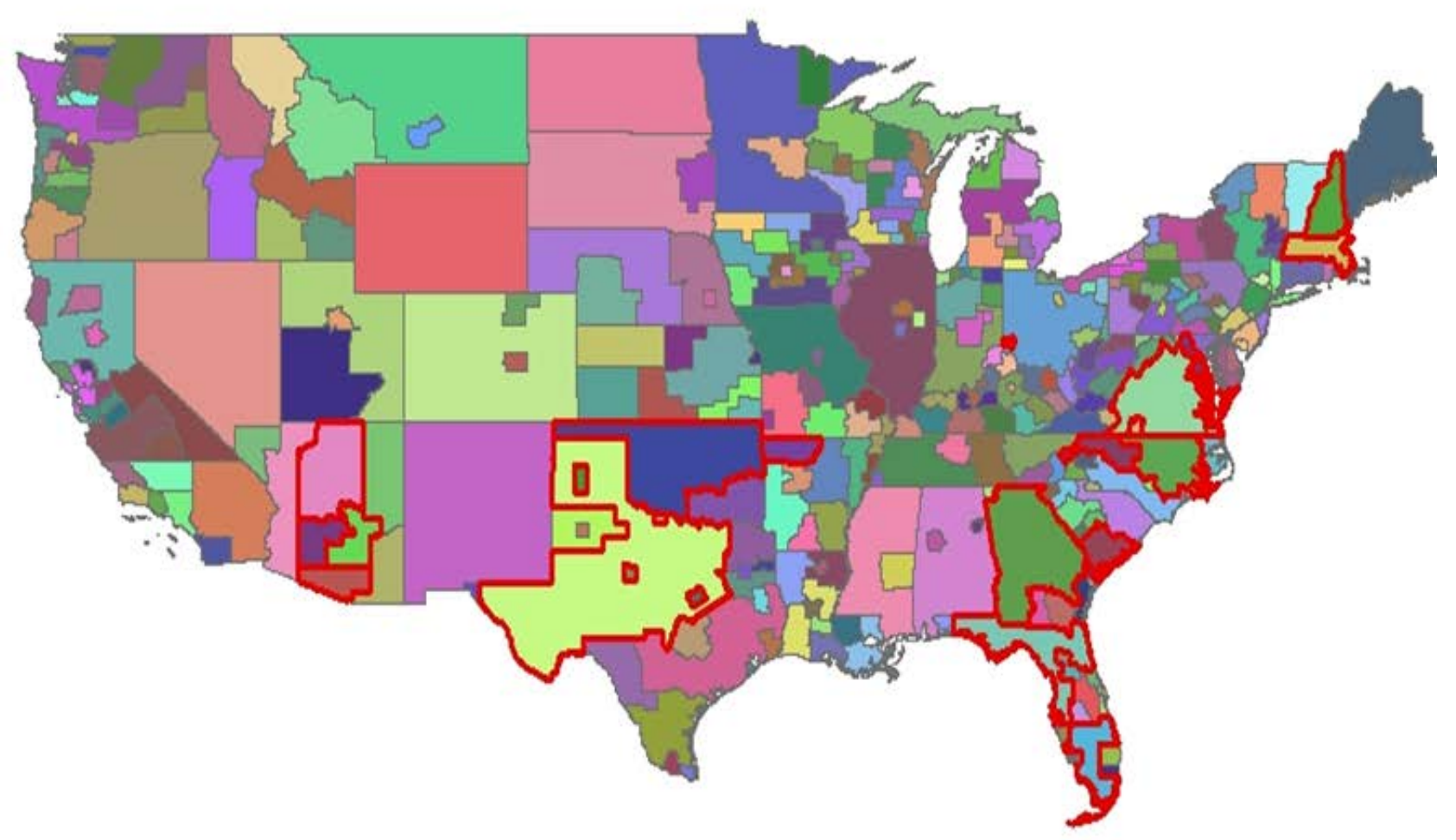


Table 1. Summary Statistics

Panel A. Summary Statistics for Aggregate Analysis (Weighted by 2005 Immigrant Population, N=2028)

$\begin{array}{cccc}\text { Mean } & \text { Std. Dev. } & \text { Min } & \text { Max } \\ & & & \\ 1,330,598 & 1,376,981 & 167 & 4,041,157 \\ 3,923,486 & 2,874,675 & 70,910 & 9,263,624 \\ & & & \\ 0.01 & 0.07 & -6.99 & 0.92 \\ 0.04 & 0.13 & -12.86 & 1.00 \\ -0.03 & 0.11 & -12.91 & 0.92 \\ 0.03 & 0.02 & 0.00 & 1.21 \\ 0.01 & 0.01 & 0.00 & 0.48 \\ 0.03 & 0.03 & 0.00 & 2.10 \\ 0.16 & 0.04 & 0.00 & 1.00 \\ 0.03 & 0.02 & 0.00 & 0.83 \\ 0.02 & 0.02 & 0.00 & 0.61 \\ 0.02 & 0.01 & 0.00 & 0.61 \\ 0.01 & 0.01 & 0.00 & 0.61 \\ & & & \\ 0.02 & 0.12 & 0.00 & 1.33 \\ 0.16 & 0.33 & 0.00 & 1.14 \\ 0.18 & 0.42 & 0.00 & 2.00 \\ & & & \\ 0.03 & 0.02 & -0.04 & 0.13 \\ 0.03 & 0.03 & -0.13 & 0.14 \\ 0.18 & 0.05 & -0.02 & 0.31 \\ 0.04 & 0.02 & 0.00 & 0.08\end{array}$

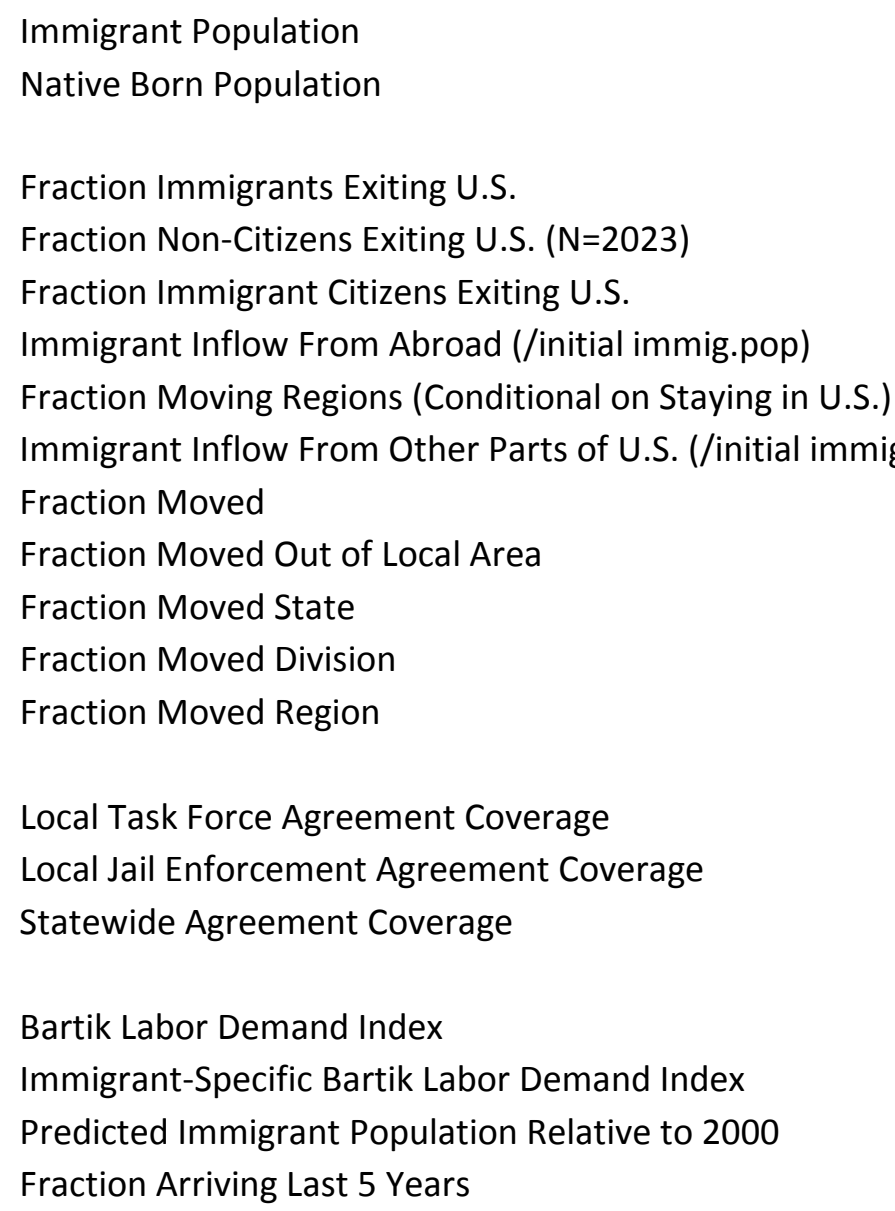

0.04

Panel B. Summary Statistics for Individual Analysis of Immigrants Remaining in U.S. (Weighted by ACS Survey Weights, $\mathrm{N}=1,081,129$ ) Sample is 18-to-49-year-old non-institutionalized foreign born in U.S. for two consecutive years

\begin{tabular}{|c|c|c|c|c|}
\hline & Mean & Std. Dev. & Min & Max \\
\hline Moved & 0.18 & 0.38 & 0.00 & 1.00 \\
\hline Moved Out of Local Area & 0.04 & 0.19 & 0.00 & 1.00 \\
\hline Moved Out of State & 0.03 & 0.16 & 0.00 & 1.00 \\
\hline Moved Division & 0.02 & 0.14 & 0.00 & 1.00 \\
\hline Moved Region & 0.01 & 0.12 & 0.00 & 1.00 \\
\hline Local Task Force Agreement Coverage & 0.02 & 0.12 & 0.00 & 1.33 \\
\hline Local Jail Enforcement Agreement Coverage & 0.16 & 0.33 & 0.00 & 1.14 \\
\hline Statewide Agreement Coverage & 0.17 & 0.41 & 0.00 & 2.00 \\
\hline State E-Verify & 0.07 & 0.25 & 0.00 & 1.00 \\
\hline In-state Tuition & 0.56 & 0.50 & 0.00 & 1.00 \\
\hline Bartik Labor Demand Index & 0.03 & 0.02 & -0.04 & 0.13 \\
\hline Immigrant-Specific Bartik Labor Demand Index & 0.02 & 0.03 & -0.16 & 0.18 \\
\hline Local Area Unemployment Rate & 0.08 & 0.03 & 0.02 & 0.21 \\
\hline Predicted Immigrant Population Relative to 2000 & 0.19 & 0.04 & -0.03 & 0.32 \\
\hline Arrived Last 5 Years & 0.18 & 0.39 & 0.00 & 1.00 \\
\hline Male & 0.52 & 0.50 & 0.00 & 1.00 \\
\hline Married & 0.59 & 0.49 & 0.00 & 1.00 \\
\hline High School Degree & 0.28 & 0.45 & 0.00 & 1.00 \\
\hline Some College & 0.17 & 0.38 & 0.00 & 1.00 \\
\hline College Grad or More & 0.25 & 0.43 & 0.00 & 1.00 \\
\hline Age & 34.89 & 8.45 & 18.00 & 49.00 \\
\hline
\end{tabular}


Table 2. Effects of Enforcement on Annual Cross-Border Migration (Aggregate Analysis) 2005-2011

1

Fraction Exited U.S.

(mean=0.013)

\begin{abstract}
$0.1041 * *$
(0.0204)

$-0.0066$

(0.0153)

$-0.0060$

(0.0094)

$-0.3220$

(0.5672)

$-0.5804^{*}$

(0.2763)

0.3252

(0.2593)

$4.9548 * *$

(0.6609)
\end{abstract}

Year Dummies

Local Area Dummies

Number of Observations

R-Squared
Fraction Exited U.S.

Maricopa County Excluded

yes

yes

III

Inflows from Abroad (As a Inflows from Abroad (As a fraction of initial total immigrant fraction of initial total immigrant population) population)

Maricopa County Excluded

$$
\text { (mean=0.013) }
$$

$($ mean $=0.032)$

$($ mean $=0.032)$

$$
\begin{gathered}
\mathbf{0 . 0 1 0 2} \\
(0.0508) \\
-0.0140 \\
(0.0140) \\
-0.0122 \\
(0.0092) \\
-0.1309 \\
(0.5893) \\
-0.5992^{*} \\
(0.2766) \\
0.3946 \\
(0.2520) \\
5.4438 * * \\
(0.5842)
\end{gathered}
$$

$-0.0121 * *$
$(0.0034)$
-0.0027
$(0.0043)$
-0.0021
$(0.0020)$
-0.1033
$(0.1341)$
0.1294
$(0.0805)$
0.0306
$(0.0473)$
$-0.3553^{* *}$
$(0.0940)$

$-0.0056$

$(0.0074)$

$-0.0003$

(0.0039)

$-0.0016$

(0.0022)

$-0.1162$

(0.1362)

$0.1365+$

(0.0804)

0.0273

(0.0481)

$-0.3633 * *$

(0.1026)

yes

yes

yes

yes

2028
0.186

2022

0.187

2028

0.493

2022

0.491

Notes: Standard errors clustered by local area reported in parentheses. $+, *, * *$ indicate statistical significance at the 10,5 , and 1 percent levels.

There are 338 local areas, 51 states, 9 divisions, and 4 regions.

Analysis at the local area-year level and weighted by immigrant population in 2005. 


\section{Table 3. Effects of Enforcement on Internal Migration to Other Regions (Aggregate Analysis)}

$\begin{array}{cc} & \text { Fraction Moved to } \\ \text { Fraction Moved Homes } & \text { Different Local Area } \\ \text { (Conditional on } & \text { (Conditional on } \\ \text { Remaining In U.S.) } & \text { Remaining In U.S.) }\end{array}$

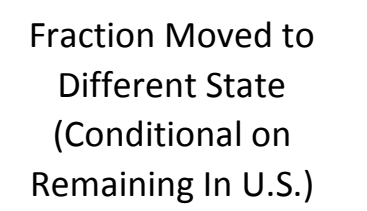

Fraction Moved to

Fraction Moved to
Different Census Region

Remaining In U.S.)

(Conditional on

Remaining In U.S.)

Inflow from Other Parts of U.S. (As A Fraction of Initial Immigrant or Native Population)

Panel A. Immigrants (Including Maricopa, N=2028) Task Force Enforcement

(mean $=0.157)$
0.0105
$(0.0113)$
0.0060
$(0.0095)$
-0.0061
$(0.0051)$

$($ mean $=0.156)$
-0.0132
$(0.0216)$
0.0088
$(0.0099)$
-0.0050
$(0.0054)$

$\begin{array}{cc}(\text { mean }=0.161) & (\text { mean }=0.043) \\ -0.0104 & -0.0044 \\ (0.0075) & (0.0028) \\ \mathbf{0 . 0 1 8 9 *} & \mathbf{0 . 0 0 1 0} \\ (0.0094) & (0.0031) \\ \mathbf{0 . 0 0 0 3} & \mathbf{0 . 0 0 3 3 ^ { * * }} \\ (0.0025) & (0.0011)\end{array}$

Panel C. Natives (Including Maricopa, N=2028)

Task Force Enforcement

Jail Enforcement

Statewide Enforcement

Panel D. Natives (Excluding Maricopa, $\mathrm{N}=2022$ )

Task Force Enforcement

Jail Enforcement

Statewide Enforcement

$($ mean $=0.160)$
$-0.0220+$
$(0.0115)$
$0.0198+$
$(0.0104)$
-0.0002
$(0.0023)$

(mean $=0.033)$
$0.0090^{*}$
$(0.0043)$
-0.0048
$(0.0043)$
$\mathbf{0 . 0 0 2 0}$
$(0.0020)$

$0.0099^{* *}$

$(0.0033)$

$-0.0029$

$(0.0026)$

$-0.0012$

(0.0020)

(mean=0.033)

0.0123

$(0.0100)$

$-0.0049$

(0.0049)

0.0019

$(0.0021)$

(mean $=0.022)$

0.0138

$0.0086)$

$-0.0021$

(0.0028)

$-0.0010$

(0.0021)

$($ mean $=0.016)$
$0.0083^{*}$
$(0.0035)$
$-0.0043+$
$(0.0026)$
-0.0013
$(0.0018)$

$($ mean $=0.016)$
$0.0158^{*}$
$(0.0071)$
-0.0040
$(0.0029)$
-0.0011
$(0.0019)$

$($ mean $=0.019)$
-0.0023
$(0.0022)$
$\mathbf{0 . 0 0 2 2}$
$(0.0022)$
0.0010
$(0.0008)$

$($ mean $=0.019)$
$\mathbf{0 . 0 0 0 5}$
$(0.0028)$
$\mathbf{0 . 0 0 1 0}$
$(0.0022)$
$\mathbf{0 . 0 0 0 6}$
$(0.0008)$

(mean=0.012

0.0054**

(0.0020)

$-0.0019$

$(0.0021)$

$-0.0013$

(0.0009)

(mean $=0.012)$

0.0096*

0.0048)

$-0.0007$

(0.0019)

$-0.0009$

(0.0009)

$($ mean $=0.026)$
$-\mathbf{0 . 0 0 3 2 +}$
$(0.0018)$
$\mathbf{0 . 0 0 1 8}$
$(0.0019)$
$\mathbf{0 . 0 0 1 7}$
$(0.0011)$

(0.0011)

$($ mean $=0.042)$
-0.0021
$(0.0052)$
-0.0000
$(0.0034)$
$0.0030^{*}$
$(0.0012)$

(mean $=0.026)$
-0.0027
$(0.0033)$
$\mathbf{0 . 0 0 1 0}$
$(0.0019)$
$\mathbf{0 . 0 0 1 4}$
$(0.0012)$

(mean $=0.014)$

$-0.0025$

$0.0016)$

0.0029+

$(0.0016)$

0.0006

(0.0005)

$($ mean $=0.032)$
0.0026
$(0.0086)$
-0.0143
$(0.0103)$
0.0005
$(0.0048)$

$($ mean $=0.033)$
-0.0039
$(0.0157)$
-0.0155
$(0.0114)$
-0.0002
$(0.0052)$

$($ mean $=0.039)$
0.0018
$(0.0035)$
-0.0050
$(0.0040)$
-0.0011
$(0.0020)$

$($ mean $=0.039)$
0.0008
$(0.0060)$
-0.0056
$(0.0045)$
-0.0012
$(0.0021)$

Notes: Standard errors clustered by local area reported in parentheses.,$+ *{ }^{* *}$ indicate statistical significance at the 10,5 , and 1 percent levels. There are 338 local areas, 51 states, 9 divisions, and 4 regions.

Analysis at the local area-year level and weighted by immigrant population in 2005. All regressions include full set of controls shown in Table 2. 
Table 4. Effects of Enforcement on Internal Migration (Individual Linear Probability Models)

Sample Includes Noninstutionalized Foreign-Born Individuals 18-49 Living in the United States for Two Consecutive Years

III $\quad$ IV

Moved Out of Local Moved Out of Local Area

$$
\text { Area }
$$

Maricopa Coun
Excluded

(mean=0.038)

(mean=0.038)

0.0084*

$(0.0042$

$-0.0030$

$(0.0041)$

0.0019

$(0.0023)$

$-0.0369$

(0.1396)

$-0.0910$

$-0.1259^{* *}$

$(0.0426)$

$0.0153^{* *}$

$(0.0012)$

$0.0044^{* *}$
$(0.0005)$

$(0.0005)$
$-0.0067^{* *}$

$(0.0015)$

$0.0032^{* *}$

$(0.0007)$

$0.0040^{* *}$
$(0.0009)$

$0.0216^{* *}$

(0.0021)

yes

yes
yes$$
\text { yes }
$$

1,081,12

0.022
Moved Out of State Moved Out of State

Maricopa County

Excluded

(mean=0.025)

(mean $=0.025)$

0.0141

$(0.0094)$

$-0.0007$

(0.0025)

$-0.0015$

(0.0026)

$-0.0933$

(0.1113)

$-0.0426$

(0.0620)

$-0.0870^{* *}$

(0.0304)

$0.0136^{* *}$

(0.0010)

$0.0028^{* *}$

(0.0004)

$-0.0036^{* *}$

(0.0009)

$(0.0007)$

$0.0017+$
$(0.0010)$

$0.0181^{* *}$

(0.0023)

yes
yes
yes
yes
062,600
0.021

VI

VII

Moved Out of Census Moved Out of Census Moved Out of Census Moved Out of Census Division Division Region Region

Maricopa County

$$
\text { Excluded }
$$$$
\text { Excluded }
$$

(mean=0.019)

(mean=0.019)

(mean=0.014)

(mean=0.014)

$0.0098^{* *}$
$(0.0037)$
-0.0030
$(0.0023)$
-0.0022
$(0.0021)$
0.1261
$(0.0780)$
$-0.1388^{* *}$
$(0.0492)$
$-0.0525+$
$(0.0279)$
$0.0105^{* *}$
$(0.0007)$
$0.0020^{* *}$
$(0.0002)$
$-0.0025^{* *}$
$(0.0007)$
$0.0015^{* *}$
$(0.0005)$
0.0012
$(0.0008)$
$0.0144^{* *}$
$(0.0018)$
yes
yes
yes
yes
$1,081,129$
0.016

\begin{tabular}{c}
\hline $0.0077^{* *}$ \\
$(0.0020)$ \\
-0.0011 \\
$(0.0016)$ \\
$-0.0020^{*}$ \\
$(0.0010)$ \\
0.0764 \\
$(0.0695)$ \\
$-0.0958^{*}$ \\
$(0.0405)$ \\
$-0.0392+$ \\
$(0.0235)$ \\
$0.0080^{* *}$ \\
$(0.0006)$ \\
$0.0016^{* *}$ \\
$(0.0002)$ \\
$-0.0018^{* *}$ \\
$(0.0005)$ \\
$0.0009+$ \\
$(0.0005)$ \\
0.0011 \\
$(0.0007)$ \\
$0.0117^{* *}$ \\
$(0.0014)$ \\
yes \\
yes \\
yes \\
yes \\
$1,081,129$ \\
0.014
\end{tabular}

$0.0122^{*}$

$(0.0056)$

$-0.0002$

$(0.0016)$

$-0.0017$

(0.0010)

0.0667

(0.0697)

$-0.0900 *$

(0.0403)

$-0.0409+$

(0.0234)

$0.0080 * *$

(0.0006)

$0.0016^{* *}$

(0.0002)

$-0.0019^{* *}$

(0.0005)

$0.0010+$

(0.0005)

0.0011

(0.0007)

$0.0118^{* *}$

$(0.0014)$

yes

yes

,062,600

0.014

Notes: Standard errors clustered by local area reported in parentheses.,$+ * * *$ indicate statistical significance at the 10,5 , and 1 percent levels.

There are 338 local areas, 51 states, 9 divisions, and 4 regions.

Analysis at the individual level and weighted by ACS survey weights. 
Table 5. Effects of Task Force Enforcement on Internal Migration of Immigrants and Natives Sample Includes Noninstutionalized Individuals 18-64 Living in the United States for Two Consecutive Years

Excludes Maricopa County

Panel A. Immigrants $(\mathrm{N}=1,062,600)$ Task Force Enforcement

Panel B. Natives $(\mathrm{N}=5,911,822)$ Task Force Enforcement

Panel C. Natives (Reweighted, $\mathrm{N}=5,696,693$ ) Task Force Enforcement

$$
\begin{gathered}
\text { (mean }=0.038) \\
0.0118 \\
(0.0096) \\
\\
(\text { mean }=0.057) \\
-0.0024 \\
(0.0057) \\
\\
(\text { mean }=0.050) \\
-0.0082 \\
(0.0059)
\end{gathered}
$$

0.0200

Task Force Enforcement

(0.0123)

$$
\begin{gathered}
\text { (mean }=0.025) \\
0.0140 \\
(0.0094) \\
\\
(\text { mean }=0.036) \\
-0.0045 \\
(0.0028) \\
\\
(\text { mean }=0.031) \\
-0.0064 \\
(0.0040)
\end{gathered}
$$

0.0204+
Fraction Moved Out of Census

$$
\text { In U.S.) }
$$

Fraction Moved Out of Census

U.S.)

$($ mean $=0.019)$
$0.0182^{*}$
$(0.0080)$

$($ mean $=0.025)$
-0.0024
$(0.0024)$

$($ mean $=0.022)$
-0.0044
$(0.0041)$


$\mathbf{0 . 0 2 2 6 *}$
$(0.0100)$

$($ mean $=0.014)$
$0.0122^{*}$

$0.0122 *$
$(0.0056)$

(mean $=0.018$ )

$-0.0027$

(0.0018)

(mean $=0.016)$

$-0.0048$

(0.0033)

0.0170*

Notes: Standard errors clustered by initial local area are reported in parentheses. $+, *, * *$ indicate statistical significance at the 10,5 , and 1 percent levels.

Analysis at the individual level. All regressions include full set of controls shown in Table 4. Panel D shows coefficient on interaction term from a fully interacted model.

There are 337 local areas (excluding Maricopa County), 51 states, 9 divisions, and 4 regions.

Reweighting based on initial local area- sex-age category-education category cells, where weights make natives comparable to immigrants on those dimensions.

Cells with no immigrants are dropped in Panels C and D. 
Table 6. Responses to Enforcement By Citizenship and Education

Sample Includes Noninstutionalized Individuals 18-49 Living in the United States for Two Consecutive Years

Excludes Maricopa County

$\begin{array}{lcccc} & \text { Less Educated } & \text { More Educated } & \text { Less Educated } & \text { More Educated } \\ \text { All Immigrants } & \text { Non-Citizens } & \text { Non-Citizens } & \text { Naturalized Citizens } & \text { Natualized Citizens } \\ (\mathrm{N}=1,062,600) & (\mathrm{N}=406,842) & (\mathrm{N}=241,042) & (\mathrm{N}=163,885) & (\mathrm{N}=250,831)\end{array}$

Panel A. Moved Out of Census Division

(mean=0.019)

(mean=0.014)

(mean=0.033)

(mean=0.012)

(mean=0.018)

Task Force Enforcement

$0.0182 *$

$(0.0080)$

Jail Enforcement

Statewide Enforcement

$-0.0030$

(0.0025)

$-0.0020$

(0.0023)

$\mathbf{0 . 0 1 0 0}$
$(0.0126)$
$-\mathbf{0 . 0 0 2 8}$
$(0.0047)$
$\mathbf{0 . 0 0 0 8}$
$(0.0040)$

$0.0418^{* *}$

$(0.0142)$

$-0.0026$

$(0.0067)$

$-0.0057$

(0.0038)

0.0101
$(0.0091)$
$-0.0114+$
$(0.0063)$
$-0.0069^{*}$
$(0.0029)$

$\mathbf{0 . 0 1 4 1 +}$

(0.0085)

0.0049

$(0.0051)$

$-0.0031$

(0.0027)

Panel B. Moved Out of Census Region

(mean=0.014)

(mean=0.010)

(mean=0.026)

(mean=0.009)

(mean=0.014)

Task Force Enforcement

0.0122*

(0.0056)

Jail Enforcement

$-0.0002$

(0.0016)

Statewide Enforcement

$-0.0017$

(0.0010)

0.0292*

(0.0131)

$-0.0004$

$(0.0041)$

$-0.0046$

(0.0030)

0.0068
$(0.0064)$
-0.0035
$(0.0051)$
$-0.0042 *$
$(0.0017)$

0.0079

(0.0072)

0.0048

$(0.0044)$

0.0002

(0.0021)

(0.0022)

Notes: Standard errors clustered by initial local area are reported in parentheses. $+, *, * *$ indicate statistical significance at the 10,5 , and 1 percent levels. Analysis at the individual level. All regressions include full set of controls shown in Table 4.

There are 337 local areas (excluding Maricopa County), 51 states, 9 divisions, and 4 regions.

"Less educated" is defined as those with a high school degree or less. 


\section{Table 7. Conditional Logit Estimates of Location Choice 18-to-29-year-old non-citizens with at least some college (Odds Ratios Reported)}

$\begin{array}{cc}\mathbf{0 . 4 9 2 1 +} & \mathbf{0 . 4 4 1 2 *} \\ (0.1938) & (0.1503) \\ \mathbf{3 . 3 3 9 0 * *} & 3.4561^{* *} \\ (0.9990) & (1.0678) \\ 1.0671 & 1.0676 \\ (0.0651) & (0.0664) \\ 8,538.6361^{* *} & 8,678.0020^{* *} \\ (393.7431) & (403.8164)\end{array}$

Same*Arrived Last Five Years

Same* College Grad
Task Force Enforcement
Jail Enforcement
Statewide Enforcement
Origin-Destination Pair Avg
Immigrant-Specific Bartik Labor Demand
Fraction Same Country of Origin Group
Predicted Immigration Relative to 2000
Potential Destination is Same as Initial Location
Same*Male

Task Force Enforcement
Jail Enforcement
Statewide Enforcement
Origin-Destination Pair Avg
Immigrant-Specific Bartik Labor Demand
Fraction Same Country of Origin Group
Predicted Immigration Relative to 2000
Potential Destination is Same as Initial Location
Same*Male

Task Force Enforcement
Jail Enforcement
Statewide Enforcement
Origin-Destination Pair Avg
Immigrant-Specific Bartik Labor Demand
Fraction Same Country of Origin Group
Predicted Immigration Relative to 2000
Potential Destination is Same as Initial Location
Same*Male

Task Force Enforcement
Jail Enforcement
Statewide Enforcement
Origin-Destination Pair Avg
Immigrant-Specific Bartik Labor Demand
Fraction Same Country of Origin Group
Predicted Immigration Relative to 2000
Potential Destination is Same as Initial Location
Same*Male

Task Force Enforcement
Jail Enforcement
Statewide Enforcement
Origin-Destination Pair Avg
Immigrant-Specific Bartik Labor Demand
Fraction Same Country of Origin Group
Predicted Immigration Relative to 2000
Potential Destination is Same as Initial Location
Same*Male
II
Yes

0.5276
$(0.2215)$
$2.0460+$
$(0.7690)$
1.0498
$(0.0582)$
$6,761.3573^{* *}$
$(5,294.2007)$
$39.0962^{* *}$
$(25.5602)$
$20,589.7723^{* *}$
$(12,049.1545)$
$10,505.9997^{* *}$
$(6,142.2227)$
1.5619
$(1.0370)$
$0.9187^{*}$
$(0.0355)$
$0.8859^{*}$
$(0.0525)$
$0.4735^{* *}$
$(0.0269)$

No
Yes
$0.4177^{*}$

(0.1768)

2.1113+

(0.8188)

1.0501

(0.0587)

$7,001.3559 * *$

$(5,549.1287)$

$38.1552^{* *}$

(25.2900)

$18,442.1781^{* *}$

$(11,080.8045)$

$10,387.2453^{* *}$

$(6,102.7159)$

1.5540

(1.0429)

$0.9184 *$

(0.0357)

$0.8777^{*}$

(0.0522)

$0.4692^{* *}$

(0.0273)

No

Note: Standard errors clustered by initial local area are reported in parentheses. $+,{ }^{*},{ }^{* *}$ indicate statistical significance at the 10,5 , and 1 percent levels. Columns I and III allow 338 choices for the potential destination; columns II and IV exclude Maricopa County as an initial location and potential destination. 
Appendix Table 1. Robustness

Sample Includes Noninstutionalized Foreign-Born Individuals 18-49 Living in the United States for Two Consecutive Years
II
IV V
VII
VIII

Moved Out of Moved Out of Moved Out of Moved Out of Moved Out of Moved Out of Moved Out of Moved Out of Moved Out of Moved Out of Moved Out of Moved Out of Census Division Census Division Census Division Census Division Census Division Census Division Census Region Census Region Census Region Census Region Census Region Census Region

\begin{tabular}{|c|c|c|c|c|c|c|c|c|c|c|c|c|}
\hline \multirow{2}{*}{ Task Force Enforcement } & $0.0182^{*}$ & $0.0171^{*}$ & $0.0191^{*}$ & $0.0179 *$ & $0.0209 * *$ & $2.7638^{*}$ & $0.0122^{*}$ & $0.0112^{*}$ & $0.0127^{*}$ & $0.0128^{*}$ & $0.0161^{*}$ & $2.6876^{*}$ \\
\hline & $(0.0080)$ & $(0.0077)$ & $(0.0074)$ & $(0.0082)$ & $(0.0079)$ & (1.1997) & $(0.0056)$ & $(0.0055)$ & $(0.0052)$ & $(0.0057)$ & $(0.0069)$ & $(1.2287)$ \\
\hline Jail Enforcement & $\begin{array}{l}-0.0030 \\
(0.0025)\end{array}$ & $\begin{array}{l}-0.0010 \\
(0.0028)\end{array}$ & $\begin{array}{l}-0.0022 \\
(0.0033)\end{array}$ & $\begin{array}{l}-0.0030 \\
(0.0025)\end{array}$ & $\begin{array}{l}-0.0035 \\
(0.0022)\end{array}$ & $\begin{array}{l}\mathbf{0 . 7 1 9 9} \\
(0.1550)\end{array}$ & $\begin{array}{l}-0.0002 \\
(0.0016)\end{array}$ & $\begin{array}{c}0.0013 \\
(0.0017)\end{array}$ & $\begin{array}{c}0.0003 \\
(0.0022)\end{array}$ & $\begin{array}{l}-0.0002 \\
(0.0016)\end{array}$ & $\begin{array}{l}-0.0012 \\
(0.0017)\end{array}$ & $\begin{array}{c}0.8210 \\
(0.1423)\end{array}$ \\
\hline Statewide Enforcement & $\begin{array}{l}-0.0020 \\
(0.0023)\end{array}$ & $\begin{array}{l}-0.0017 \\
(0.0024)\end{array}$ & $\begin{array}{l}-0.0018 \\
(0.0026)\end{array}$ & $\begin{array}{l}-0.0024 \\
(0.0021)\end{array}$ & & $\begin{array}{c}0.9996 \\
(0.0931)\end{array}$ & $\begin{array}{l}-0.0017 \\
(0.0010)\end{array}$ & $\begin{array}{l}-0.0015 \\
(0.0011)\end{array}$ & $\begin{array}{l}-0.0015 \\
(0.0012)\end{array}$ & $\begin{array}{l}-0.0010 \\
(0.0012)\end{array}$ & & $\begin{array}{c}0.9598 \\
(0.0536)\end{array}$ \\
\hline Local Area Unemployment Rate & & & $\begin{array}{l}0.0639^{*} \\
(0.0261)\end{array}$ & & & & & & $\begin{array}{c}0.0566^{* *} \\
(0.0208)\end{array}$ & & & \\
\hline In-State Tuition & & & & $\begin{array}{c}0.0033 \\
(0.0244)\end{array}$ & & & & & & $\begin{array}{c}0.0081 \\
(0.0193)\end{array}$ & & \\
\hline E-Verify & & & & $\begin{array}{c}0.0007 \\
(0.0021)\end{array}$ & & & & & & $\begin{array}{l}-0.0013 \\
(0.0015)\end{array}$ & & \\
\hline Bartik Labor Demand & $\begin{array}{c}0.1083 \\
(0.0781)\end{array}$ & & & $\begin{array}{c}0.1045 \\
(0.0784)\end{array}$ & $\begin{array}{c}0.0135 \\
(0.1175)\end{array}$ & $\begin{array}{c}56.8835 \\
(189.3502)\end{array}$ & $\begin{array}{c}0.0667 \\
(0.0697)\end{array}$ & & & $\begin{array}{c}0.0691 \\
(0.0694)\end{array}$ & $\begin{array}{l}-0.0062 \\
(0.1066)\end{array}$ & $\begin{array}{c}18.2342 \\
(61.3280)\end{array}$ \\
\hline Immigrant-Specific Bartik Labor Demand & $\begin{array}{c}-0.1305^{* *} \\
(0.0493)\end{array}$ & & & $\begin{array}{c}-0.1260^{*} \\
(0.0497)\end{array}$ & $\begin{array}{l}-0.1350^{*} \\
(0.0656)\end{array}$ & $\begin{array}{l}0.0280^{*} \\
(0.0501)\end{array}$ & $\begin{array}{c}-0.0900^{*} \\
(0.0403)\end{array}$ & & & $\begin{array}{r}-0.0950^{*} \\
(0.0413)\end{array}$ & $\begin{array}{l}-0.0764 \\
(0.0584)\end{array}$ & $\begin{array}{c}0.0630 \\
(0.1121)\end{array}$ \\
\hline Predicted Immigrant Population & $\begin{array}{l}-0.0557^{*} \\
(0.0276)\end{array}$ & & $\begin{array}{c}-0.0779 * * \\
(0.0253)\end{array}$ & $\begin{array}{r}-0.0556^{*} \\
(0.0276)\end{array}$ & $\begin{array}{l}-0.0595 \\
(0.0365)\end{array}$ & $\begin{array}{l}0.0208^{* *} \\
(0.0269)\end{array}$ & $\begin{array}{c}-0.0409+ \\
(0.0234)\end{array}$ & & $\begin{array}{c}-0.0572^{* *} \\
(0.0213)\end{array}$ & $\begin{array}{c}-0.0411+ \\
(0.0234)\end{array}$ & $\begin{array}{l}-0.0327 \\
(0.0331)\end{array}$ & $\begin{array}{l}0.0257^{* *} \\
(0.0359)\end{array}$ \\
\hline Arrived Last Five Years & $\begin{array}{c}0.0106^{* *} \\
(0.0007)\end{array}$ & & $\begin{array}{l}0.0106^{* *} \\
(0.0007)\end{array}$ & $\begin{array}{c}0.0106 * * \\
(0.0007)\end{array}$ & $\begin{array}{c}0.0106^{* *} \\
(0.0007)\end{array}$ & $\begin{array}{c}1.5259^{* *} \\
(0.0404)\end{array}$ & $\begin{array}{l}0.0080^{* *} \\
(0.0006)\end{array}$ & & $\begin{array}{l}0.0080^{* *} \\
(0.0006)\end{array}$ & $\begin{array}{l}0.0080^{* *} \\
(0.0006)\end{array}$ & $\begin{array}{r}0.0081^{* *} \\
(0.0006)\end{array}$ & $\begin{array}{l}1.5253^{* *} \\
(0.0469)\end{array}$ \\
\hline Male & $\begin{array}{c}0.0020^{* *} \\
(0.0002)\end{array}$ & & $\begin{array}{l}0.0020^{* *} \\
(0.0002)\end{array}$ & $\begin{array}{c}0.0020^{* *} \\
(0.0002)\end{array}$ & $\begin{array}{c}0.0020^{* *} \\
(0.0002)\end{array}$ & $\begin{array}{c}1.1205^{* *} \\
(0.0164)\end{array}$ & $\begin{array}{c}0.0016 * * \\
(0.0002)\end{array}$ & & $\begin{array}{c}0.0016^{* *} \\
(0.0002)\end{array}$ & $\begin{array}{l}0.0016^{* *} \\
(0.0002)\end{array}$ & $\begin{array}{c}0.0016 * * \\
(0.0002)\end{array}$ & $\begin{array}{l}1.1273^{* *} \\
(0.0185)\end{array}$ \\
\hline Married & $\begin{array}{c}-0.0025^{* *} \\
(0.0007)\end{array}$ & & $\begin{array}{c}-0.0025 * * \\
(0.0007)\end{array}$ & $\begin{array}{c}-0.0025^{* *} \\
(0.0007)\end{array}$ & $\begin{array}{c}-0.0025^{* *} \\
(0.0007)\end{array}$ & $\begin{array}{c}0.8762^{* *} \\
(0.0294)\end{array}$ & $\begin{array}{c}-0.0019 * * \\
(0.0005)\end{array}$ & & $\begin{array}{c}-0.0019^{* *} \\
(0.0005)\end{array}$ & $\begin{array}{c}-0.0019 * * \\
(0.0005)\end{array}$ & $\begin{array}{c}-0.0019 * * \\
(0.0005)\end{array}$ & $\begin{array}{c}0.8786^{* *} \\
(0.0305)\end{array}$ \\
\hline High School Degree & $\begin{array}{c}0.0015^{* *} \\
(0.0005)\end{array}$ & & $\begin{array}{l}0.0015^{* *} \\
(0.0005)\end{array}$ & $\begin{array}{c}0.0015^{* *} \\
(0.0005)\end{array}$ & $\begin{array}{c}0.0015^{* *} \\
(0.0005)\end{array}$ & $\begin{array}{c}1.1534^{* *} \\
(0.0428)\end{array}$ & $\begin{array}{l}0.0010+ \\
(0.0005)\end{array}$ & & $\begin{array}{l}0.0010+ \\
(0.0005)\end{array}$ & $\begin{array}{l}0.0010+ \\
(0.0005)\end{array}$ & $\begin{array}{l}0.0010+ \\
(0.0005)\end{array}$ & $\begin{array}{c}1.1604^{* *} \\
(0.0581)\end{array}$ \\
\hline Some College & $\begin{array}{c}0.0012 \\
(0.0008)\end{array}$ & & $\begin{array}{c}0.0012 \\
(0.0008)\end{array}$ & $\begin{array}{c}0.0012 \\
(0.0008)\end{array}$ & $\begin{array}{c}0.0011 \\
(0.0008)\end{array}$ & $\begin{array}{l}1.1159^{*} \\
(0.0611)\end{array}$ & $\begin{array}{c}0.0011 \\
(0.0007)\end{array}$ & & $\begin{array}{c}0.0011 \\
(0.0007)\end{array}$ & $\begin{array}{c}0.0011 \\
(0.0007)\end{array}$ & $\begin{array}{c}0.0010 \\
(0.0007)\end{array}$ & $\begin{array}{l}1.1520^{*} \\
(0.0726)\end{array}$ \\
\hline College Grad or More & $\begin{array}{c}0.0144^{* *} \\
(0.0018)\end{array}$ & & $\begin{array}{c}0.0144^{* *} \\
(0.0018)\end{array}$ & $\begin{array}{c}0.0144^{* *} \\
(0.0018)\end{array}$ & $\begin{array}{c}0.0144^{* *} \\
(0.0018)\end{array}$ & $\begin{array}{c}2.0629^{* *} \\
(0.1358)\end{array}$ & $\begin{array}{c}0.0118^{* *} \\
(0.0014)\end{array}$ & & $\begin{array}{c}0.0118^{* *} \\
(0.0014)\end{array}$ & $\begin{array}{c}0.0118^{* *} \\
(0.0014)\end{array}$ & $\begin{array}{c}0.0118^{* *} \\
(0.0014)\end{array}$ & $\begin{array}{c}2.1661^{* *} \\
(0.1454)\end{array}$ \\
\hline Age Category Dummies & yes & & yes & yes & & yes & yes & & yes & yes & yes & yes \\
\hline Country of Origin Category Dummies & yes & & yes & yes & & yes & yes & & yes & yes & yes & yes \\
\hline Year Dummies & yes & yes & yes & yes & yes & yes & yes & yes & yes & yes & yes & yes \\
\hline $\begin{array}{l}\text { Local Area Dummies } \\
\text { State*Year Dummies }\end{array}$ & yes & yes & yes & yes & $\begin{array}{l}\text { yes } \\
\text { yes }\end{array}$ & yes & yes & yes & yes & yes & $\begin{array}{l}\text { yes } \\
\text { yes }\end{array}$ & yes \\
\hline Observations & $1,062,600$ & $1,062,600$ & $1,062,600$ & $1,062,600$ & $1,062,600$ & $1,061,977$ & $1,062,600$ & $1,062,600$ & $1,062,600$ & $1,062,600$ & $1,062,600$ & $1,061,977$ \\
\hline R-squared & 0.016 & 0.009 & 0.016 & 0.016 & 0.017 & & 0.014 & 0.008 & 0.014 & 0.014 & 0.015 & \\
\hline
\end{tabular}

Notes: Standard errors clustered by local area reported in parentheses. $+, *, * *$ indicate statistical significance at the 10,5 , and 1 percent levels.

There are 337 local areas (excluding Maricopa), 51 states, 9 divisions, and 4 regions.

Analysis at the individual level and weighted by ACS survey weights. 